\title{
Pengaruh Motivasi Terhadap Prestasi Pegawai Pada Pusdiklat Tenaga Administrasi Kementerian Agama RI Ciputat-Tangerang
}

\author{
N. Lilis Suryani \\ Dosen Fakultas Ekonomi Universitas Pamulang \\ Email : dosen00437@unpam.ac.id
}

\begin{abstract}
ABSTRAK
Tujuan Penelitian ini adalah untuk mengetahui pengaruh motivasi terhadap prestasi kerja pegawai pada Pusdiklat Tenaga Administrasi Kementrian Agama RI Ciputat-Tangerang.

Penelitian ini bersifat kuantitatif untuk penelitian yang bertujuan sebagai penelitian terapan mengunakan eksperimen atau survey yaitu dengan menggunakan questioner, populasi yang dijadikan obyek dalam penelitian ini adalah seluruh karyawan yang bekerja pada Pusdiklat Kementerian Agama yang berjumlah 53 orang, sampel yang diambil dalam penelitian ini ialah sampel jenuh, yamg artinya semua populasi dijadikan sebagai sampel penelitian yakni 53 orang pegawai Pusdiklat Tenaga Administrasi Kementerian Agama Ciputat Tangerang.

Pengaruh motivasi terhadap prestasi kerja pegawai pada Pusdiklat Tenaga Administrasi Kementerian Agama RI Ciputat berdasarkan hasil analisa data menunjukan bahwa dari hasil korelasi dapat disimpulkan terdapat pengaruh yang sedang antara motivasi terhadap prestasi kerja pegawai Pada Pusdiklat Tenaga Administrasi Kementerian Agama RI Ciputat. Hasil determinasi (KD) menunjukan bahwa motivasi memberikan kontribusi atau sumbangan sebesar 8.841\% terhadap prestasi kerja pegawai Pada Pusdiklat Tenaga Administrasi Kementerian Agama RI Ciputat. Sementara, dari hasil perhitungan analisis regresi linier sederhana, dapat dinilai $\mathrm{Y}=34,36+0,114(\mathrm{X})$ hal ini berarti jika nilai variable Motivasi (Y) naik 1 (Satuan), maka dapat meningkatkan variable Prestasi Kerja (X) sebesar 0,779 hasil perhitungan uji hipotesis maka dapat dilihat bahwa, $t_{\text {hitung }} 8,841 \%>t_{\text {tabel }} 1,675 \%$ maka menunjukan Ha diterima Ho ditolak, yang berarti bahwa terdapat pengaruh yang sangat signifikan antara motivasi terhadap prestasi kerja pegawai pada Pusdiklat Tenaga Administrasi Kementrian Agama RI Ciputat.
\end{abstract}

Kata Kunci : Motivasi, Prestasi Kerja. 


\section{PENDAHULUAN}

\section{Latar Belakang Masalah}

Kualitas manusia sebagai tenaga kerja merupakan modal dasar dalam masapembangunan. Tenaga kerjayang berkualitas akan menghasilkan suatu hasil kerja yangoptimal sesuai dengan target kerjanya.Manusia sebagai tenaga kerja atau pegawaimerupakan sumber daya yang penting bagi perusahaan, karena mereka mempunyai bakat,tenaga dan kreativitas yang sangat dan dibutuhkan oleh perusahaan untuk mencapai tujuannya.

Pelaksaan pekerjaan oleh para pegawai di lingkungan sebuah perusahaan pada dasarnya berlangsung dalam kondisi pegawai sebagai manusia. Suasana batin/psikologis seorang pegawaisangat besar pengaruhnya pada pelaksaan pekerjaan. Halini terlihat dalam semangat atau gairah kerja yang mengasilkan kegiatan kerja sebagai kontribusi bagi pencapaian tujuan bisnis perusahaan tempatnya bekerja. Dari segi psikologis kenyataan menunjukkan bahwa bergairah atau semangat dan sebaliknya tidak bergairah atau tidak bersemangat seorang pegawai dalam melaksanakan pekerjaannya, sangat dipengaruhi oleh motivasi kerja yang mendorongnya. Dengan kata lain setiap pegawai membutuhkan motivasi kerja agar semangat kerjanya timbul dan mempunyai semangat kerja yang baru. Oleh karena itu, untuk mewujudkannya diperlukan Sumber Daya Manusia (SDM) yang terampil dan handal dibidangnya. Salah satu cara untuk mengembangkan Sumber Daya Manusia (SDM) dalam perusahaan yaitu dengan jalan meningkatkan kompetensi individu pegawai pada perusahaan tersebut.

Tiap manajemen perlu mengelola dan mengetahui seberapa besar presetasi kerja pegawainya, apakah dapat mencapai tujuan perusahaan atau tidak. Dengan mengetahui prestasi kerja, perusahaan akan lebih mengetahui seberapa jauh pengembangan mutu Sumber Daya Manusia (SDM) pegawai yang telah berhasil denan efektif sehingga menghasilkan prestasi dengan baik dan maksimal. Dengan demikian, dapat diketahui faktor-faktor apa yang mempengaruhinprestasi kerja, baik ditinjau dari individu maupun faktor lingkungan kerja.

Prestasi kerja pegawai merupakan salah satu indikator keberhasilan operasi perusahaan dalam mencapai suatu tujuan yang diingin perusahaan. Salah satu usaha yang tepat untuk dilakukan agar mereka mau berkerja dengan giat adalah dengan cara memberikan motivasi terhadap semua pegawai diperusahaan.

Pada dasarnya penilaian prestasi kerja dilaksanakan berdasarkan kesepakatan pelaksanaan suatu pekerjaan antara atasan dan stafnya, yang selanjutnya dimonitor dan disimpulkan selama masa penilaian berlangsung dan pengertian penilaian prestasi kerja merupakan usaha membandingkan antara hasil kerja yang dicapai oleh seorang pegawai dengan standar prestasi yang telah ditetapkan oleh perusahaan.

Dalam penelitian ini, penulis memilih Pusdiklat Kementerian Agama RI terdiri sejak pada tanggal 3 Januari 1946 yang diumumkan oleh Pemerintah Negara RI di 
Yogyakarta. Pusdiklat Tenaga Administrasi Kementerian Agama RI yang berpusat di tangerang terletak di Jl. H. Juanda No.37, CiputatTangerang Selatan.

Pusdiklat Tenaga Administrasi adalah salah satu unit kerja eselon II di lingkungan Badan Litbang dan Diklat Kementerian Agama bersama dengan Pusdiklat Tenaga Administrasi, terdapat 6 (enam) unit kerja Eselon II lainnya, masingmasing Pusat Penelitian dan Pengembangan (Puslitbang) kehidupan keagamaan, Puslitbang Pendidikan Agama dan Keagamaan. Puslitbang lektur Agama dan Keagamaan, Pusdiklat Tenaga Teknis Keagamaan dan Sekretariat Badan Litbang dan Diklat.

Oleh karena itu, peningkatan motivasi yang tinggidari hasil kerja yang peneliti lakukan pada tahun 2017 terdapat beberapa masalah pada Pusdiklat Tenaga Administrasi Kementerian Agama RI CiputatTangerang. Masalah tersebut meliputi belum optimalnya motivasi yang diberikan pimpinan, sehingga menyebabkan pegawai kurang bersemangat dalam bekerja. Selain itu pegawai belum optimal dalam menyelesaikan pekerjaan, banyaknya pegawai yang kurang disiplin akan tingkat absensinya serta kurang harmonisnya hubungan antara pegawai dengan atasan.

Berdasarkan latar belakang diatas, maka penulis tertarikuntuk melakukan penelitian lebih jauh mengenai "Pengaruh Motivasi Terhadap Prestasi Pegawai Pada Pusdiklat Tenaga Administrasi Kementerian Agama RI CiputatTangerang".

\section{Indentifikasi Masalah}

Berdasarkan latar belakang masalah yang telah diuraikan di atas penulis perlu mengidentifikasi permasalahan yang ada, antara lain :

1. Belum optimalnya motivasi kerja yg diberikan.

2. Rendahnya tingkat prestasi kerja pegawai.

3. Banyaknya pegawai yang kurang semangat dalam bekerja.

4. Kurang harmonisnya hubungan antara pegawai dengan atasan.

5. Tingkat kedisiplinan pegawai yang masih rendah.

\section{Perumusan Masalah}

Berdasarkan identifikasi dan pembatasan masalah diatas, maka penulis merumuskan masalah sebagai berikut:

1. Bagaimana motivasi pegawaipada Pusdiklat Tenaga Administrasi Kementrian Agama RI CiputatTangerang?

2. Bagaimana prestasi kerja pegawai Pusdiklat Tenaga Administrasi Kementrian Agama RI CiputatTangerang?

3. Seberapa besar pengaruh motivasi terhadap prestasi kerja Pegawai Administrasipada Pusdiklat Tenaga Administrasi Kementrian Agama RI Ciputat-Tangerang?

\section{Kerangka Berpikir}

Menurut Uma Sekar dalam Sugiono (2011:60) mengemukakan bahwa "Kerangka berfikir merupakan model konseptual tentang bagaimana teori berhubungan dengan berbagai faktor yang telah diidentifikasi sebagai hal yang penting"

Melihat pada konteks di atas, maka penulis ini akan melihat faktorfaktor apa saja yang dapat mempengaruhi motivasi kerja pegawai serta prestasi kerja pegawai 
"PENGARUH MOTIVASI TERHADAP PRESTASI KERJA

KARYAWAN PADA PUSDIKLAT TENAGA ADMINISTRASI

KEMENTRIAN AGAMA RI CIPUTAT-TANGERANG"

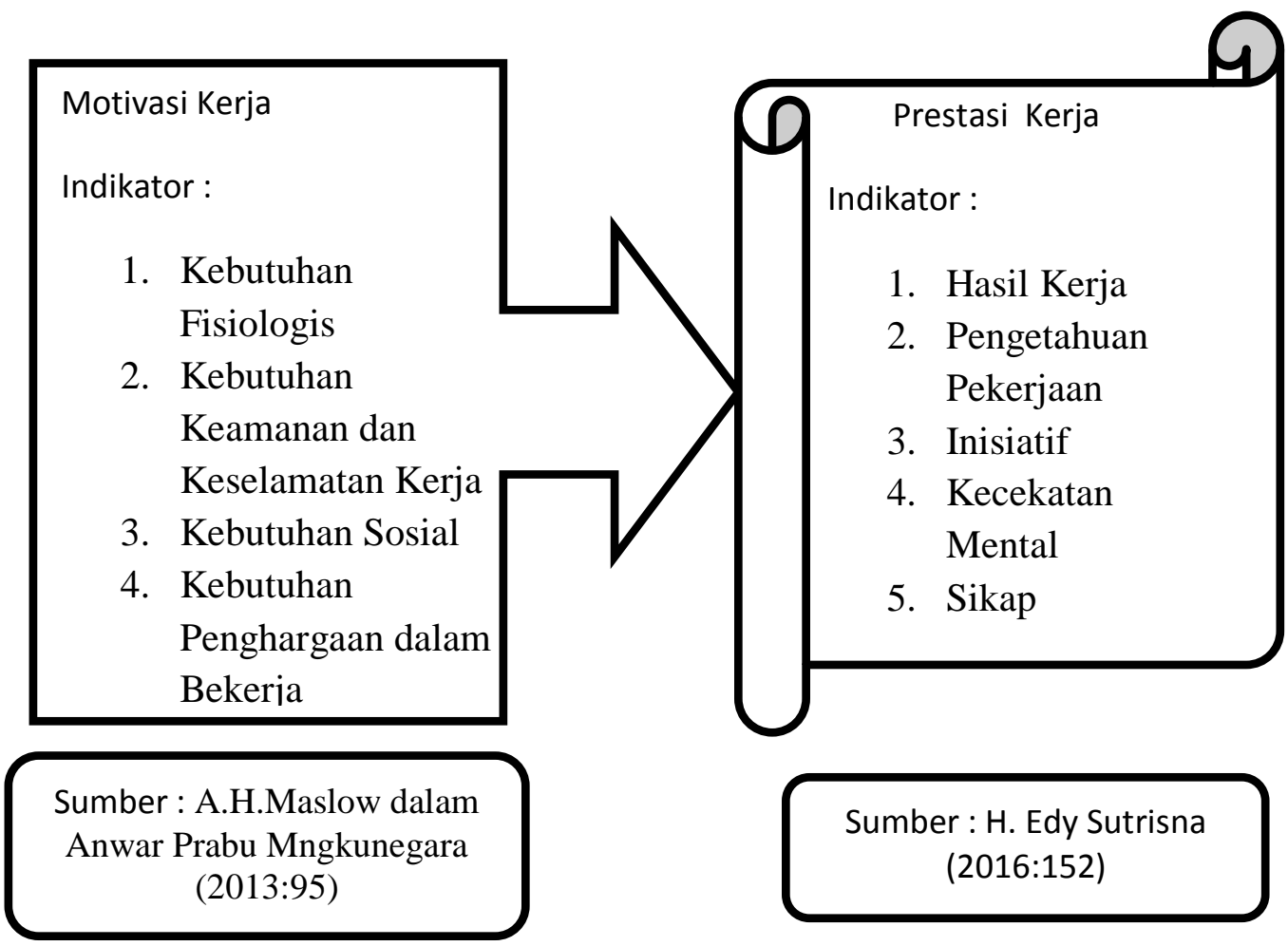

\section{Kerangka Berfikir}

\section{LANDASAN TEORI}

\section{Motivasi}

Motivasi berasal dari kata latin movere yang berarti dorongan, daya penggerak atau kekuatan yang menyebabkan suatu tindakan atau perbuatan. Kata movere, dalam bahasa inggris sering disepadankan dengan motivator yang berarti pemberian motif, penimbulan motif, atau hal yang menimbulkan dorongan atau keadaanyang menimbulkan dorongan. Secara harfiah motivasi berarti pemberian motif. Seseorang melakukan sesuatu dengan sengaja, tentu ada suatu maksud atau tujuan mendorongnya melakukan suatu tndakan. Motif dasar dari seseorang tersebut adalah adanya kebutuhan orang tersebut akan kebanggaan dan kehormatan serta, mungkin limpahan materi.

\section{Menurut Wayne F. Cascio} dalam Sunyoto (2012:11) menyatakan bahwa motivasi adalah suatu kekuatan yang dihasilkan dari keinginan seseorang untuk memuaskan kebutuhannya. Lain halnya dengan pengertian motivasi yang diungkapkan oleh Ardana (2012:193) yang menyatakan bahwa motivasi merupakan kekuatan yang mendorong seseorang untuk melakukan suatu tindakan atau tidak pada hakekatnya ada secara internal dan eksternal yang dapat positif atau negatif untuk mengarahkannya 
sangat bergantung kepada ketangguhan sang manajer.

Jadi secara umum definisi motivasi dapat diartikan sebagai suatu tujuan atau pendorong, dengan sebenarnya tersebut yang daya penggerak utama bagi seseorang dalam berupaya dalam mendapatkan atau mencapai apa yang diinginkannya baik itu positif ataupun negatif.

Penganut content theory ini cukup banyak, yang satu sama lain sebenarnya tidak mempunyai kaitan. Akan tetapi, berdasarkan penelitian yang

dilakukan

mereka, ternyata hasil penemuannya dapat dimasukan dalam teori kebutuhan.

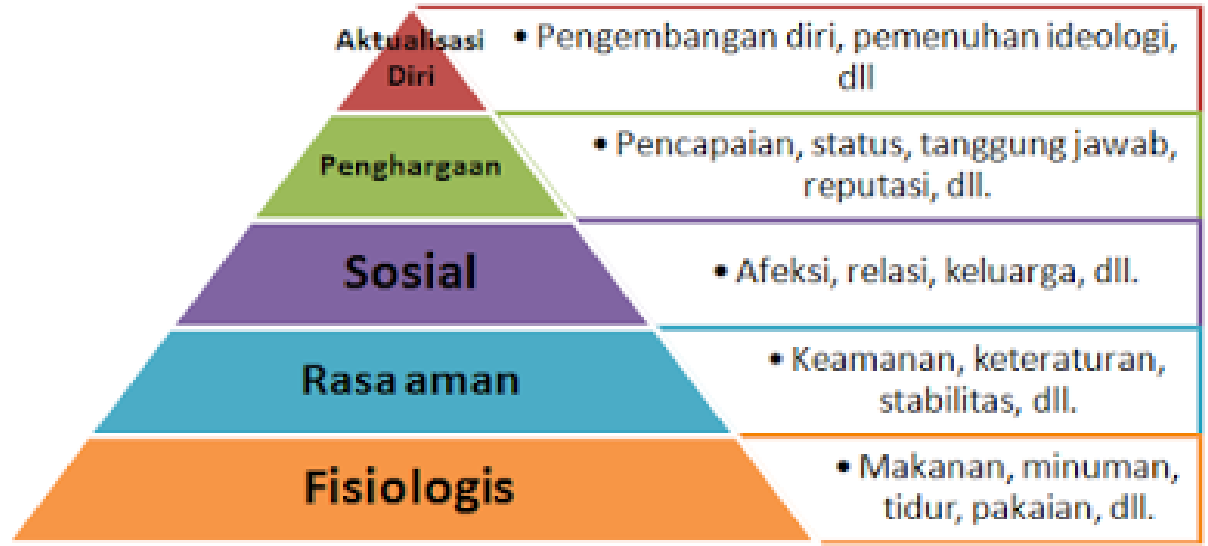

Gambar 1.2 Hierarki Kebutuhan Maslow dalam Anwar Prabu Mngkunegara (2013:95)

\section{Prestasi Kerja}

Menurut Bernardin dan Russel dikutip H. Edy Sutrisno (2016:150) menyatakan: "Prestasi adalah catatan tentang hasil-hasil yang diperoleh dari fungsi-fungsi pekerjaan tertentu atau kegiatan tertentu selama kurun waktu tertentu.

Menurut H. Melayu S. P. Hasibuan (2014:94) menyatakan: “ Prestasi kerja adalah suatu hasil kerja yang dicapai seseorang dalam melaksanakan tugas-tugas yang dibebankan kepadanya yang didasarkan atas kecakapan, pengalaman, dan kesuguhan serta waktu.

$\quad \begin{gathered}\text { Menurut Anwar Prabu } \\ \text { Mangkunegara }\end{gathered}$
menyatakan: “

hasil kerja secara kualitas dan kuantitas yang dicapai oleh seseorang pegawai dalam melaksanakan tugasnya sesuai dengan tanggung jawab yang diberikan kepadanya.

Menurut Rivai (2011:274) menyatakan: "Prestasi kerja adalah proses melalui mana organisasiorganisasi mengevaluasi atau menilai prestasi kerja pegawai.

Jadi prestasi kerja dapat disimpulkan sebagai hasil kerja seseorang pegawai selama priode tertentu dibandingkan dengan berbagai kemungkinan misalnya standard target/sasaran atau kriteria yang telah ditentukan terlebih dahulu dan disepakati bersama. 


\section{METODE PENELITIAN}

Penelitian ini dilaksanakan pada Pusdiklat Tenaga Administrasi Kementerian Agama, yang beralamat J1. Ir. H. Juanda No.37, Cempaka Putih, Ciputat Timur, Kota Tangerang Selatan, Banten 15412.

Penelitian yang dilakukan penulis dalam penyusunan penelitian ini adalah kuantitatif untuk penelitian yang bertujuan sebagai penelitian terapan. Untuk penelitian yang sifatnya penelitian terapan dapat mengunakan eksperimen atau survey yaitu dengan menggunakan questioner (Sugiyono 2016;7).

Populasi dalam setiap penelitian harus disebutkan secara tersurat, yaitu berkenanan dengan besarnya anggota populasi serta wilayah yang dicakup. Menurut Sugiyono (2016:80) populasi adalah wilayah generalisasi yang terdiri atas obyek atau subyek yang mempunyai kualitas dan karakteristik tertentu yang ditetapkan oleh peneliti untuk dipelajari dan kemudian ditarik kesimpulannya.

Berdasarkan pada tempat penelitian yang telah ditetapkan, maka populasi yang dijadikan obyek dalam penelitian ini adalah seluruh karyawan yang bekerja pada Pusdiklat Kementerian Agama yang berjumlah 53 orang.

Menurut Sugiyono (2016:81) Sampel adalah bagian dari jumlah dan karakteristik yang dimiliki oleh populasi tersebut. Bila populasi besar, dan peneliti tidak mungkin mempelajari semua yang ada pada populasi, misalnya karena keterbatasan dana, tenaga dan waktu, maka peneliti dapat menggunakan sampel yang diambil dari populasi itu. Apa yang dipelajari dari simpel itu, kesimpulannya akan dapat diberlakukan untuk populasi. Untuk itu sampel yang diambil dari populasi harus betul-betul representatif (mewakili).

Dikarenakan jumlah populasi relatif kecil sehingga sampel yang diambil dalam penelitian ini ialah sampel jenuh, yamg artinya semua populasi dijadikan sebagai sampel penelitian yakni 53 orang pegawai Pusdiklat Tenaga Administrasi Kementerian Agama Ciputat Tangerang.

\section{PEMBAHASAN DAN HASIL}

\section{A. Karakteristik Responden}

1. Data Responden Berdasarkan Pendidikan

\section{Data Responden Berdasarkan Pendidikan}

\begin{tabular}{|c|c|c|c|}
\hline No. & Pendidikan & Jumlah & $\begin{array}{c}\text { Persentase } \\
(\mathbf{\%})\end{array}$ \\
\hline 1. & S3 & 2 & $3,77 \%$ \\
\hline 2. & S2 & 22 & $41,51 \%$ \\
\hline 3. & S1 & 17 & $32,08 \%$ \\
\hline 4. & SD & 12 & $22,64 \%$ \\
\hline & Jumlah & $\mathbf{5 3}$ & $\mathbf{1 0 0 \%}$ \\
\hline
\end{tabular}

Sumber: Hasil Pengolahan Data 2017

Berdasarkan data diatas dapat dilihat bahwa Pusdiklat Tenaga Administrasi Kementerian Agama RI Ciputat jenjang pendidikan S2 yaitu 22 orang atau $41,51 \%, \mathrm{~S} 1$ yaitu 17 orang atau 32,08\%, SD yaitu 12 orang atau $22,64 \%, S 3$ yaitu 2 orang atau $3,77 \%$.

\section{Data Responden Berdasarkan Usia}


Data Responden Berdasarkan Usia

\begin{tabular}{|c|c|c|c|}
\hline No. & Usia & Jumlah & $\begin{array}{c}\text { Persentase } \\
(\%)\end{array}$ \\
\hline 1. & $30-39$ & 14 & $26,42 \%$ \\
\hline 2. & $40-49$ & 18 & $33,96 \%$ \\
\hline 3. & $50-59$ & 21 & $39,62 \%$ \\
\hline & Jumlah & $\mathbf{5 3}$ & $\mathbf{1 0 0 \%}$ \\
\hline
\end{tabular}

Sumber : Hasil Pengolahan Data 2017

Berdasarkan data diatas dapat dilihat bahwa di Pusdiklat Tenaga Administrasi Kementerian Agama Ciputat usia banyak adalah 50-59 tahun yaitu 21 orang atau $39,62 \%$, 40-49 tahun yaitu 18 orang atau $33,96 \%, 30-39$ tahun yaitu 14 orang atau $26,42 \%$.

\section{Data Responden Berdasarkan jenis Kelamin}

Data Responden Berdasarkan Jenis Kelamin

\begin{tabular}{|c|c|c|c|}
\hline No. & $\begin{array}{c}\text { Jenis } \\
\text { Kelamin }\end{array}$ & Jumlah & $\begin{array}{c}\text { Persentase } \\
(\mathbf{\%})\end{array}$ \\
\hline 1. & Laki-laki & 28 & $52,83 \%$ \\
\hline 2. & Perempuan & 25 & $47,17 \%$ \\
\hline & Jumlah & $\mathbf{5 3}$ & $\mathbf{1 0 0 \%}$ \\
\hline
\end{tabular}

Sumber: Hasil Pengolahan Data 2017

Berdasarkan tabel diatas Nampak bahwa responden dalam penelitian ini didominasi oleh lakilaki yaitu sebanyak 28 pegawai atau sebesar 52,83\%. Sedangkan responden perempuan sebanyak 25 pegawai atau sebesar $47,17 \%$.

\section{B. Hasil Penelitian \\ 1. Uji Validitas}

Hasil validitas Instrumen Motivasi

(X)

\begin{tabular}{|c|c|c|c|}
\hline No. & r hitung & r table & Keterangan \\
\hline 1 & 0,356 & 0,266 & Valid \\
\hline 2 & 0,334 & 0,266 & Valid \\
\hline 3 & 0,670 & 0,266 & Valid \\
\hline 4 & 0,495 & 0,266 & Valid \\
\hline 5 & 0,399 & 0,266 & Valid \\
\hline 6 & 0,687 & 0,266 & Valid \\
\hline 7 & 0,522 & 0,266 & Valid \\
\hline 8 & 0,723 & 0,266 & Valid \\
\hline 9 & 0,865 & 0,266 & Valid \\
\hline 10 & 0,406 & 0,266 & Valid \\
\hline
\end{tabular}

Sumber : Data Olahan Kuesioner 2017

Dari tabel diatas dapat diketahui bahwa $r$ hitung $>r$ tabel 0,266 maka pengujian validitas seluruh instrument variabel motivasi (x) dinyatakan valid.

\section{a. Uji Reliabilitas Variabel Motivasi (x)}

Suatu instrumen dikatakan reliabel jika dapat dipercaya untuk mengumpulkan data penelitian. Sugiyono (2013:354) pengujian reliabilitas instrument dapat dilakukan secara eksternal maupun internal. Secara eksternal pengujian dapat dilakukan dengan test-test (stability), equivalen, dan gabungan keduanya.Secara internal reliabilitas instrumen dapat diuji dengan menganaliisis konsistensi butir-butir yang ada pada instrument dengan teknik tertentu.

Mencari Varian Butir Instrumen Motivasi (x)

Varians butir ini sendiri dapat diperoleh dengan menggunakan rumus berikut:

$\sigma h^{2}=\frac{\Sigma \mathrm{xi}^{2}-\frac{(\Sigma \mathrm{Xi})^{2}}{\mathrm{n}}}{\mathrm{n}}$ 
Diketahui :

$\sigma \mathrm{h}^{2}=$ Variand butir pernyataan ke-1

$\mathrm{n} \quad=53 \quad$ Jumlah

responden

$\Sigma X i=209$ Skor jawaban subyek untuk pernyataan ke-n

$\Sigma \mathrm{Xi}^{2}=875 \quad$ Jumlah butir instrumen yang di kuadratkan

$$
\begin{aligned}
\sigma \mathrm{h}^{2} & =\frac{50.830}{53} \\
\sigma \mathrm{h}^{2} & =0,959
\end{aligned}
$$

untuk perhitungan varian butir instrument no 2 (dua) s/d no 10 (sepuluh) digunakan dengan cara dan rumus yang sama dengan perhitungan varian butir instrument no 1 (satu) diatas. Berikut di bawah ini perhitungan varian butir seluruh instrumen Motivasi (x):

\section{Hasil Varian Butir Instrumen}

\begin{tabular}{|c|c|c|c|}
\hline No. & $\Sigma X \mathbf{X}$ & $\Sigma \mathbf{X} \mathbf{i}^{2}$ & Varian Butir \\
\hline 1 & 209 & 875 & 0,959 \\
\hline 2 & 212 & 880 & 0,604 \\
\hline 3 & 210 & 859 & 0,509 \\
\hline 4 & 209 & 845 & 0,394 \\
\hline 5 & 182 & 655 & 0,567 \\
\hline 6 & 197 & 768 & 0,675 \\
\hline 7 & 199 & 802 & 0,342 \\
\hline 8 & 183 & 677 & 0,852 \\
\hline 9 & 195 & 781 & 0,199 \\
\hline 10 & 207 & 857 & 0,915 \\
\hline $\mathrm{H}$ & & & $\Sigma \sigma h^{2} 6.016$ \\
\hline
\end{tabular}
Motivasi (X)

Sumber:Data Olahan Kuesioner 2017

Dari hasil varian butir seluruh instrument motivasi (x) selanjutnya dijumlahkan, dan didapatkan hasil sebesar 6.016.

1) Mencari Varian Total Variabel Motivasi (X)

Sedangkan total varian dapat diperoleh dengan menggunakan rumus berikut:

$\sigma 1^{2}=\frac{\Sigma \mathrm{Xt}^{2}-\frac{(\Sigma \mathrm{Xt})^{2}}{\mathrm{n}}}{\mathrm{n}}$

Diketahui:

$\sigma 1^{2}=$ Variabel total yang dicari

$\mathrm{n}=$ 53Jumlah responden

$\Sigma X t=1997$ Total skor butir instrument

$\Sigma \mathrm{Xt}^{2}=75715$ Jumlah seluruh instrumen yang di kuadratkan

$\sigma 1^{2}=\frac{\Sigma 75715-\frac{(1997)^{2}}{53}}{53}$

$\sigma 1^{2}=\frac{\Sigma 75715-\frac{3988009}{53}}{53}$

$\sigma 1^{2}=\frac{\Sigma 75715-7524.545}{53}$

$\sigma 1^{2}=\frac{469.54}{53}$

$\sigma 1^{2}=8,85$

2) Mencari Reliabilitas Variabel Motivasi (x)

$\mathrm{rca}=\frac{\mathrm{k}}{(\mathrm{k}-1)}\left\{1-\frac{\Sigma \sigma \mathrm{h}^{2}}{\sigma 1^{2}}\right\}$

rca = Nilai reliabilitas instrument

$\mathrm{k} \quad=10 \quad$ Banyaknya

pertanyaan/banyaknya soal

$\Sigma \sigma \mathrm{h}^{2}=6,016 \quad$ Jumlah Varian

butir

$\sigma 1^{2}=8,85 \quad$ Varian total

rca $=\frac{10}{(10-1)}\left\{1-\frac{\Sigma 6,016}{8,85}\right\}$

rca $=\frac{10}{(9)}\{1-0,67)$

$\mathrm{rca}=1.11\{0,33\}$

$\mathrm{rca}=0,366$

hasil perhitungan reliabilitas instrumen variabel Motivasi (x) dapat diketahui bahwa $\mathrm{r}$ ca $0,366>$ 0,266 maka dapat diartikan bahwa reliabilitas variabel Motivasi (x) dinyatakan reliabel. 
b. Uji Validitas Variabel Prestasi Kerja (y)

Dasar pengambilan keputusan dalam uji validitas adalah sebagai berikut: Adapun $r$ tabel 0,266 didapat dari Tabel (r) Korelasi Product Moment dengan taraf signifikan 5\% dan sampai 53 responden, $(\mathrm{df}=\mathrm{N}-2)$ $\mathrm{df}=53-2=51,5 \%=0,266$

\begin{tabular}{|c|c|c|c|}
\hline \multicolumn{4}{|c|}{$\begin{array}{l}\text { Hasil Validitas Instrumen Prestasi } \\
\qquad \text { Kerja (y) }\end{array}$} \\
\hline No. & $r$ hitung & $r$ tabel & Keterangan \\
\hline 1 & 0,386 & 0,266 & Valid \\
\hline 2 & 0,412 & 0,266 & Valid \\
\hline 3 & 0,385 & 0,266 & Valid \\
\hline 4 & 0,476 & 0,266 & Valid \\
\hline 5 & 0,348 & 0,266 & Valid \\
\hline 6 & 0,270 & 0,266 & Valid \\
\hline 7 & 0,398 & 0,266 & Valid \\
\hline 8 & 0,537 & 0,266 & Valid \\
\hline 9 & 0,327 & 0,266 & Valid \\
\hline 10 & 0,376 & 0,266 & Valid \\
\hline
\end{tabular}

Sumber : Data Olahan Kuesioner 2017

Dari tabel diatas dapat diketahui bahwa $\mathrm{r}$ hitung $>\mathrm{r}$ tabel 0,266 maka pengujian validitas seluruh instrumen variabel prestasi kerja (y) dinyatakan valid.

\section{c.Uji Reliabilitas Variabel Prestasi} Kerja (y)

1) Mencari Varian Butir Instrumen Prestasi Kerja (y)

Varians butir ini sendiri dapat diperoleh dengan menggunakan rumus berikut:

$\sigma \mathrm{h}^{2}=\frac{\Sigma \mathrm{Yi}-\frac{(\Sigma \mathrm{Yi})^{2}}{\mathrm{n}}}{\mathrm{n}}$

Diketahui :

$\sigma \mathrm{h}^{2} \quad=$ Variand butir pernyataan ke-1 n $\quad=53 \quad$ Jumlah

responden

$\Sigma$ Yi $=210$ Skor jawaban subyek untuk pernyataan ke-n

$\Sigma \mathrm{Yi}^{2}=874$ Jumlah butir instrumen yang di kuadratkan

$\begin{aligned} \sigma \mathrm{h}^{2} & =\frac{41.924}{53} \\ \sigma \mathrm{h}^{2} & =0,791\end{aligned}$

untuk perhitungan varian butir instrument no 2 (dua) s/d no 10 (sepuluh) digunakan dengan cara dan rumus yang sama dengan perhitungan varian butir instrument no 1 (satu) diatas. Berikut di bawah ini perhitungan varian butir seluruh instrumen Prestasi Kerja (y):

\section{Hasil Varian Butir Instrumen Prestasi Kerja (y)}

\begin{tabular}{|c|c|c|c|}
\hline No. & $\boldsymbol{\Sigma} \mathbf{y i}$ & $\boldsymbol{\Sigma Y}^{\mathbf{2}}$ & Varian Butir \\
\hline 1 & 210 & 874 & 0,791 \\
\hline 2 & 203 & 807 & 0,556 \\
\hline 3 & 182 & 672 & 0,887 \\
\hline 4 & 194 & 740 & 0,563 \\
\hline 5 & 183 & 675 & 0,813 \\
\hline 6 & 200 & 790 & 0,665 \\
\hline 7 & 207 & 837 & 0,538 \\
\hline 8 & 206 & 814 & 0,251 \\
\hline 9 & 191 & 733 & 0,843 \\
\hline 10 & 193 & 739 & 0,682 \\
\hline & & & $\mathbf{\Sigma} \mathbf{\sigma h}^{\mathbf{2}} \mathbf{6 . 5 8 9}$ \\
\hline
\end{tabular}

Sumber : Data Olahan Kuesioner 2017

Dari hasil varian butir seluruh instrumen prestasi kerja (y) selanjutnya dijumlahkan dan didapatkan hasil sebesar 6.589. 
2) Mencari Varian Totasl Variabel Motivasi (X)

Sedangkan total varian dapat diperoleh dengan menggunakan rumus berikut:

$\sigma 1^{2}=\frac{\sum \mathrm{Yt}-\frac{(\Sigma \mathrm{Yt})^{2}}{\mathrm{n}}}{\mathrm{n}}$

Diketahui:

$\sigma 1^{2}=$ Variabel total yang dicari

$\mathrm{n} \quad=53 \quad$ Jumlah responden

$\Sigma$ Xt $=1969 \quad$ Total skor butir

instrument

$\Sigma \mathrm{Xt}^{2}=73675 \quad$ Jumlah seluruh instrumen yang di kuadratkan

$\sigma 1^{2}=\frac{\Sigma 73675-\frac{(1969)^{2}}{53}}{53}$

$\sigma 1^{2}=\frac{524.792}{53}$

$\sigma 1^{2}=9,90$

3) Mencari Reliabilitas Variabel Motivasi (X)

$\mathrm{rca} \quad=\frac{\mathrm{k}}{(\mathrm{k}-1)}\left\{1-\frac{\Sigma \sigma \mathrm{h}^{2}}{\sigma 1^{2}}\right\}$

rca $=$ Nilai reliabilitas instrument $\mathrm{k}=10 \quad$ Banyaknya pertanyaan/banyaknya soal

$\Sigma \sigma \mathrm{h}^{2}=6589 \quad$ Jumlah Varian

butir

$\sigma 1^{2}=9,90 \quad$ Varian total

rca $=\frac{10}{(10-1)}\left\{1-\frac{\Sigma 6.589}{9,90}\right\}$

rca $=0,377$

hasil perhitungan reliabilitas instrumen variabel Prestasi Kerja (y) dapat diketahui bahwa $\mathrm{r}$ ca0,377> 0,266 maka dapat diartikan bahwa reliabilitas variabel Prestasi Kerja (y) dinyatakan reliabel.

C. Pengaruh Motivasi Terhadap Prestasi Kerja Pegawai

1. Regresi Linear Sederhana

Untuk memperkirakan atau memperhitungkan besarnya efek atau pengaruh dari perubahaan suatu kejadian terhadap kejadian lainnya.

Fungsi linear mempunyai persamaan sebagai berikut:

$$
\begin{aligned}
& \mathrm{Y}=\mathrm{a}+\mathrm{b}(\mathrm{x}) \\
& \mathrm{b}=\frac{\mathrm{n} \cdot(\Sigma \mathrm{XX})-(\Sigma \mathrm{X})(\Sigma \mathrm{Y})}{\mathrm{n} \Sigma \mathrm{X}^{2}-(\Sigma \mathrm{X})^{2}} \\
& \mathrm{a}=\ddot{\mathrm{Y}}-\mathrm{b}
\end{aligned}
$$

(Sumber : J. Supranto (2009:181)

Hasil Regresi Linear Sederhana

\begin{tabular}{|c|c|c|c|c|c|}
\hline No. & $\mathbf{X}$ & $\mathbf{Y}$ & $\mathbf{X}^{\mathbf{2}}$ & $\mathbf{Y}^{\mathbf{2}}$ & $\mathbf{X Y}$ \\
\hline 1 & 40 & 35 & 1600 & 1225 & 1400 \\
\hline 2 & 41 & 36 & 1681 & 1296 & 1476 \\
\hline 3 & 43 & 33 & 1849 & 1089 & 1419 \\
\hline 4 & 38 & 31 & 1444 & 961 & 1178 \\
\hline 5 & 41 & 31 & 1681 & 961 & 1271 \\
\hline 6 & 36 & 40 & 1296 & 1600 & 1440 \\
\hline 7 & 37 & 31 & 1369 & 961 & 1147 \\
\hline 8 & 30 & 40 & 900 & 1600 & 1200 \\
\hline 9 & 35 & 40 & 1225 & 1600 & 1400 \\
\hline 10 & 33 & 43 & 1089 & 1849 & 1419 \\
\hline 11 & 40 & 39 & 1600 & 1521 & 1560 \\
\hline 12 & 36 & 37 & 1296 & 1369 & 1332 \\
\hline 13 & 38 & 43 & 1444 & 1849 & 1634 \\
\hline 14 & 43 & 38 & 1849 & 1444 & 1634 \\
\hline 15 & 41 & 33 & 1691 & 1089 & 1353 \\
\hline 16 & 40 & 37 & 1600 & 1369 & 1480 \\
\hline 17 & 35 & 40 & 1225 & 1600 & 1400 \\
\hline 18 & 39 & 42 & 1521 & 1764 & 1638 \\
\hline 19 & 40 & 38 & 1600 & 1444 & 1520 \\
\hline 20 & 38 & 43 & 1444 & 1849 & 1634 \\
\hline 21 & 36 & 32 & 1296 & 1024 & 1152 \\
\hline 22 & 37 & 35 & 1369 & 1225 & 1295 \\
\hline 23 & 36 & 38 & 1296 & 1444 & 1368 \\
\hline 24 & 41 & 38 & 1681 & 1444 & 1558 \\
\hline 25 & 37 & 37 & 1369 & 1369 & 1369 \\
\hline 26 & 34 & 35 & 1156 & 1225 & 1190 \\
\hline 27 & 36 & 39 & 1296 & 1521 & 1404 \\
\hline 28 & 34 & 38 & 1156 & 1444 & 1292 \\
\hline 29 & 35 & 32 & 1225 & 1024 & 1120 \\
\hline 30 & 37 & 38 & 1369 & 1444 & 1406 \\
\hline 31 & 34 & 37 & 1156 & 1369 & 1258 \\
\hline 32 & 38 & 33 & 1444 & 1089 & 1254 \\
\hline 33 & 39 & 37 & 1521 & 1369 & 1443 \\
\hline 34 & 39 & 32 & 1521 & 1024 & 1248 \\
\hline 35 & 40 & 34 & 1600 & 1156 & 1360 \\
\hline 36 & 37 & 37 & 1369 & 1369 & 1369 \\
\hline 37 & 33 & 37 & 1089 & 1369 & 1221 \\
\hline 38 & 35 & 37 & 1225 & 1369 & 1295 \\
\hline 39 & 40 & 39 & 1600 & 1521 & 1560 \\
\hline 40 & 31 & 37 & 961 & 1369 & 1147 \\
\hline 41 & 36 & 40 & 1296 & 1600 & 1440 \\
\hline 42 & 40 & 39 & 1600 & 1521 & 1560 \\
\hline & & & & & \\
\hline
\end{tabular}




\begin{tabular}{|c|c|c|c|c|c|}
43 & 38 & 34 & 1444 & 1156 & 1292 \\
\hline 44 & 38 & 37 & 1444 & 1369 & 1406 \\
\hline 45 & 41 & 36 & 1681 & 1296 & 1476 \\
\hline 46 & 39 & 35 & 1521 & 1225 & 1365 \\
\hline 47 & 41 & 37 & 1681 & 1369 & 1517 \\
\hline 48 & 43 & 38 & 1849 & 1444 & 1634 \\
\hline 49 & 40 & 40 & 1600 & 1600 & 1600 \\
\hline 50 & 34 & 39 & 1156 & 1521 & 1326 \\
\hline 51 & 35 & 42 & 1225 & 1764 & 1470 \\
\hline 52 & 41 & 39 & 1681 & 1521 & 1599 \\
\hline 53 & 38 & 41 & 1444 & 1681 & 1558 \\
\hline Total & $\mathbf{1 9 9 7}$ & $\mathbf{1 9 6 9}$ & $\mathbf{7 5 7 1 5}$ & $\mathbf{7 3 6 7 5}$ & $\mathbf{7 4 0 8 5}$ \\
\hline
\end{tabular}

\section{Sumber : Data Olahan Kuesioner} 2017

Diketahui :

rxy $=$ Nilai koefisien korelasi product moment

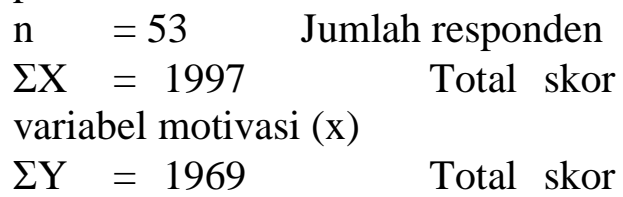

variabel prestasi kerja (y)

$\Sigma \mathrm{X}^{2}=75715 \quad$ Kuadrat skor total variabel motivasi $(\mathrm{x})$

$\Sigma X Y=74085 \quad$ Jumlah perkalian butir variabel $\mathrm{X}$ dan variabel $\mathrm{Y}$

1) Mencari nilai $b$

$\mathrm{b}=\frac{\mathrm{n} \cdot(\Sigma \mathrm{XY})-(\Sigma \mathrm{X})(\Sigma \mathrm{Y})}{\mathrm{n} \Sigma \mathrm{X}^{2}-(\Sigma \mathrm{X})^{2}}$

$\mathrm{b}=\frac{5588}{24886}$

$\mathrm{b}=0,224$

2) Mencari nilai a

Rata-rata $\mathrm{x}$ :

$\mathrm{X}=\frac{\Sigma \mathrm{Xi}}{\mathrm{n}}$

$X=\frac{1997}{53}=37,67$

Rata-rata y :

$\mathrm{Y}=\frac{\Sigma \mathrm{Yi}}{\mathrm{n}}$

$\mathrm{Y}=\frac{1969}{53}=37,15$

Nilai a :

$\mathrm{a}=\mathrm{Y}-\mathrm{bX}$

$\mathrm{a}=37,15-0,224(37,67)$

$\mathrm{a}=27,24$

3) Persamaan Regresi

Persamaan regresi $\mathrm{Y}=\mathrm{a}+\mathrm{b}(\mathrm{X})$ yang telah ditemukan adalah $\mathrm{Y}$ $=27,24+0,224(\mathrm{x})$. Jika nilai $\mathrm{X}=0$ maka $\mathrm{Y}=27,24$ dan jika $\mathrm{X}$ bertambah sebesar 1 unit maka Y bertambah. Jika perusahaan menaikan motivasi (x) sebesar 10\% maka persamaan regresi nya adalah $\mathrm{Y}=27,24+0,244(10)=29,6$.

\section{Uji Korelasi Product Moment}

Perhitungan Koefisien korelasi dalam penelitian ini untuk mengetahui besarnya Pengaruh Motivasi Terhadap Prestasi Kerja Pegawai Pada Pusdiklat Tenaga Administrasi Kementerian Agama RI Ciputat.Dan rumus untuk perhitungan korelasi dalam penelitian ini adalah kolerasi product moment.Hasil perhitungan korelasi selanjutnya di interprestasikan dengan tabel pedoman korelasi untuk mengetahui seberapa kuat pengaruh variabel motivasi (x) terhadap variabel prestasi kerja (y).

Diketahui data seperti pada tabel 4.16:

rxy $=$ Nilai koefisien korelasi product moment

$\mathrm{n}=53 \quad$ Jumlah responden

$\Sigma \mathrm{X}=1997 \quad$ Total skor variabel motivasi (x)

$\Sigma \mathrm{Y}=1969 \quad$ Total skor variabel prestasi kerja (y)

$\Sigma X^{2}=75715 \quad$ Kuadrat total skor variabel motivasi (x)

$\Sigma Y^{2}=73675 \quad$ Kuadrat total skor variabel prestasi kerja (y)

$\Sigma X Y=74085 \quad$ Jumlah perkalian butir variabel $\mathrm{X}$ dan variabel $\mathrm{Y}$

rxy $=0,212$

Dari perhitungan diatas dapat diketahui bahwa rxy selanjutnya hasil tersebut di interprestasikan dengan tabel pedoman dibawah ini: 
Hasil Korelasi dan Kekuatan Hubungan

\begin{tabular}{|c|c|}
\hline $\begin{array}{c}\text { Interval } \\
\text { Koefisien }\end{array}$ & $\begin{array}{c}\text { Tingkah } \\
\text { Hubungan }\end{array}$ \\
\hline $0,00-0,199$ & Sangat Rendah \\
$\mathbf{0 , 2 0}-\mathbf{0 , 3 9 9}$ & Rendah \\
$0,40-0,599$ & Sedang \\
$0,60-0,799$ & Kuat \\
$0,80-1,000$ & Sangat Kuat \\
\hline
\end{tabular}

Sumber : Sugiyono (2013: 231)

Setelah menginterprestasikan dengan tabel diatas dapat diketahui bahwa, hasil korelasi rxy 0,212 masuk ke dalam interval tingkah hubungan rendah, artinya terdapat pengaruh antara Motivasi Terhadap Prestasi Kerja Pegawai Pada Pusdiklat Tenaga Administrasi Kementerian Agama RI Ciputat.

\section{Uji Koefisien Determinasi}

Setelah mengetahui korelasi peason untuk mengetahui derajat hubungan antar variabel, maka selanjutnya digunakan rumus koefisien determinasi untuk menguji signifikasi hubungan, yaitu apakah hubungan yang ditemukan itu berlaku untuk seluruh populasi, sugiyono (2010:250).

Rumus koefisien determinasi yang digunakan adalah sebagai berikut:

$\mathrm{KD}=(\mathrm{r})^{2} \times 100 \%$

Dimana :

$\mathrm{KD}=$ Koefisien Determinasi

$\mathrm{r}=$ Koefisien Korelasi product moment

$\mathrm{KD}=(0,212)^{2} \times 100 \%$

$\mathrm{KD}=0,449 \times 100 \%$

Dari perhitungan diatas dapat diketahui bahwa koefisien determinasi sebesar 49,92\% yang arti nya variabel motivasi berpengaruh terhadap prestasi kerja sebesar $49,92 \%$ dan sisanya $50,08 \%$ dipengaruhi oleh faktor lainnya.

4. Uji Hipotesis (uji t)
Berdasarkan pada pokok masalah dan batasan masalah maka hipotesis sementara yang dipeneliti tetapkan pada penelitian ini adalah sebagai berikut:

$\mathrm{HO}: \mathrm{TP}=0 \quad$ Tidak terdapat pengaruh antara Motivasi

Terhadap Prestasi Kerja Pegawai Pada Pusdiklat Tenaga Administrasi Kementerian Agama RI Ciputat.

H1 : TP \# $0 \quad$ Terdapat pengaruh antara Motivasi Terhadap

Pegawai pada Pusdiklat Tenaga Prestasi Kerja Administrasi

Kementerian Agama RI Ciputat.

Langkah-langkah dalam pengujian hipotesis dalam penelitian ini adalah sebagai berikut:

1. Menentukan taraf nyata (ttabel)

Dalam menentukan taraf nyata ( $\alpha$ ) yang digunaka yaitu 0,05

Taraf signifikasi $(\alpha)=5 \%$

Taraf Kepercayaan 95 $=95 \%$

Derajat kebebasan $\quad=\mathrm{n}-2=53-2=$ 51

ttabel $(51 ; 5 \%) \quad=1,674$

2. Menentukan t-hitung menurut sugiyono (2013:230)

t $=\frac{\mathbf{r} \sqrt{\mathbf{n}-2}}{\sqrt{1-\mathbf{r}^{2}}}$

Diketahui:

$\mathrm{t}=$ Nilai thitung yang dicari

$\mathrm{n}=53$ Jumlah sampel atau responden

$\mathrm{r}=0,212$ Nilai koefisien korelasi

$\mathrm{t}=\frac{0,212 \sqrt{53-2}}{\sqrt{1-0,212^{2}}}$

$t=\frac{0,212 \sqrt{51}}{\sqrt{1-0,449}}$

$t=\frac{0,212(7,141)}{\sqrt{0,551}}$

$t=\frac{1,513892}{0,74222937424}$

$\mathbf{t}=\mathbf{2 , 0 3 9}$ 
3. pengambilan keputusan

a) Jika t hitung < ttabel, berarti $\mathrm{H} 0$ diterima dan $\mathrm{H} 1$ ditolak, artinya ada pengaruh yang signifikasi antara Motivasi Terhadap Prestasi Kerja Pegawai Pada Pusdiklat Tenaga Administrasi Kementerian Agama RI Ciputat.

b)

Jika $\mathrm{t}$ hitung > ttabel, berarti $\mathrm{H} 1$ diterima dan $\mathrm{H} 0$ ditolak, artinya pengaruh yang signifikasi antara Motivasi Terhadap Prestasi Kerja Pegawai Pada Pusdiklat Tenaga Administrasi Kementerian Agama RI Ciputat. 2. Kesimpulan

Dari hasil perhitungan $t$ hitung sebesar 2,039 dapat diketahui bahwa t hitung 2,039> t tabel 1,674 berarti H1 diterima dan Ho ditolak, artinya terdapat pengaruh yang signifikasi antara Motivasi Terhadap Prestasi Kerja Pegawai Pada Pusdiklat Tenaga Administrasi Kementerian Agama RI Ciputat.

\section{KESIMPULAN DAN SARAN Kesimpulan}

Setelah penulis melakukan penelitian dan analisis mengenai pemberian motivasi terhadap prestasi kerja pegawai untuk melihat apakah ada hubungan antara prestasi kerja pegawai pada Pusdiklat Tenaga Administrasi Kementerian Agama RI Ciputat, maka penulis dapat menarik kesimpulan sebagai berikut:

1. Motivasi pada Pusdiklat Tenaga Administrasi

Kementerian

Agama RI Ciputat sudah berjalan cukup baik. Hal tersebut ditunjukan dari jawaban responden sebesar $46,60 \%$ pegawai berpendapat bahwa motivasi dapat meningkatkan kemampuan pegawai pada
Pusdiklat Tenaga Administrasi Kementerian Agama RI Ciputat.

2. Prestasi kerja pada Pusdiklat Tenaga Administrasi Kementerian Agama RI Ciputat sudah cukup baik. Hal ini terlihat dari tanggapan responden sebesar 52,26\% pegawai sudah bekerja dengan sebaik-baiknya sehingga meningkatkan prestasi kerja.

3. Pengaruh motivasi terhadap prestasi kerja pegawai pada Pusdiklat Tenaga Administrasi Kementerian Agama RI Ciputat berdasarkan hasil analisa data menunjukan bahwa dari hasil korelasi dapat disimpulkan terdapat pengaruh yang sedang antara motivasi terhadap prestasi kerja pegawai Pada Pusdiklat Tenaga Administrasi Kementerian Agama RI Ciputat. Hasil determinasi (KD) menunjukan bahwa motivasi memberikan kontribusi atau sumbangan sebesar $8.841 \%$ terhadap prestasi kerja pegawai Pada Pusdiklat Tenaga Administrasi Kementerian Agama RI Ciputat. Sementara, dari hasil perhitungan analisis regresi linier sederhana, dapat dinilai $\mathrm{Y}=34,36+0,114(\mathrm{X})$ hal ini berarti jika nilai variable Motivasi (Y) naik 1 (Satuan), maka dapat meningkatkan variable Prestasi Kerja (X) sebesar 0,779 hasil perhitungan uji hipotesis maka dapat dilihat bahwa, $t_{\text {hitung }} 8,841 \%>t_{\text {tabel }}$ $1,675 \%$ maka menunjukan $\mathrm{Ha}$ diterima Ho ditolak, yang berarti bahwa terdapat pengaruh yang sangat signifikan antara motivasi terhadap prestasi kerja pegawai pada Pusdiklat Tenaga 
Administrasi Kementrian Agama RI Ciputat.

\section{Saran}

Adapun saran-saran yang akan penulis sampaikan yang sekiranya dapat memberikan manfaat bagi pihak-pihak terkait atau hasil penelitian ini adalah sebagai berikut:

1. Pegawain Pada Pusdiklat Tenaga Administrasi Kementrian Agama RI Ciputat - Tangerang perlu meningkatkan motivasi kerja pegawainya agar pegawainya dapat berprestasi dalam bekerja. Dari hasil penelitian serta rekapitulasi jawaban responden pegawai diketahuai bahwa prestasi pegawai masih tergolong pada kriteria kurang baik sehingga pegawai Pusdiklat Tenaga Administrasi Kementrian Agama RI Ciputat - Tangerang perlu meningkatkan motivasi kerja pegawai untuk mencapai kinerja pegawai menjadi sangat baik.

2. Memberikan kompensasi yang merata, seperti peningkatan tunjangan kinerja, menciptakan kondisi lingkungan kerja yang kondusif serta pemberian reward terhadap pegawai yang berprestasi.

\section{DAFTAR PUSTAKA}

Abdullah, M. Ma'ruf, "Manajemen dan Evaluasi Kinerja Karyawan", Aswara Pressindo, Jakarta 2014

Dessler, Gari, "Manajemen Sumber Daya Manusia". Penerbit Indeks, Jakarta 2011

Eko Widodo, Suparno, "Manajemen Pengembangan Sumber Daya
Manusia", Cetakan I dan II.Yogyakarta, 2015.

Fahmi, Irham, "Manajemen Sumber Daya Manusia Teori dan Aplikasih",

Alfabeta, Bandung, 2016.

Hanggraeni, Dewi, "Manajemen Sumber Daya Manusia", Penerbit Fakultas Ekonomi Universitas Indonesia, Jakarta 2012

Mangkunegara, AA Anwar Prabu, "Manajemen Sumber Daya Manusia”, Cetakan ke Sebelas , PT Remaja Rosdakarya, Bandung 2013

Melayu S.P. Hasibuan, "Manajemen Sumber Daya Manusia", Edisi Revisi Cetakan ke Sebelas, PT Bumi Aksara, Jakarta 2014

Melayu S.P. Hasibuan, "Manajemen Sumber Daya Manusia”. Edisi Revisi Cetakan ke Sebelas, PT Bumi Aksara, Jakarta 2014

Siswanto, H.B., "Pengantar Manajemen”, Cetakan Ketujuh, PT Bumi Askara, Jakarta, 2011

Sugiyono, "Metode Penelitian Kuantitatif, Kualitatif, dan $R \& D ”, \quad$ Alfabeta, Bandung 2016

Sutrisno Edy, M.Si, "Manajemen Sumber Daya Manusia", Prenada Media Group, Jakarta 2016

Sutrisno Edy, M.Si, "Manajemen Sumber Daya Manusia”, 
Prenada Media Group, Jakarta 2016

Suwatno dan Donni Juni Priansa, "Manajemen Sumber Daya Manusia Dalam Organisasi Publik dan Bisnis", Bandung 2011

Sugiyono, "Metode Penelitian Pendidikan", Bandung 2011

Sugiyono, "Memahami Penelitian Kuantitaf", Alfabeta, Bandung 2012

Sugiyono, "Metode Penelitian, Kuantitatif, Kualitatif,dan $R \& N$,, Alfabeta, Bandung 2013
Sugiyono, "Metode Penelitian Kuantitatif dan Kualitatif', Alfabeta, Bandung 2016

Sutrisno Edy, M,Si, "Manajemen Sumber Daya Manusia", Prenada Media Group, Jakarta 2012

Sutrisno Edy, M,Si, "Manajemen Sumber Daya Manusia", Prenada Media Group, Jakarta 2013

Sutrisno Edy, M,Si, "Manajemen Sumber Daya Manusia”, Prenada Media Group, Jakarta 2016

Wibowo, "Manajemen Kinerja", Edisi ke Tiga, Rajawali Pers 130, Jakarta 2012 